\title{
Pedofilia w Holandii: przyczyny, konsekwencje, ocena moralna
}

\author{
Andrzej Kobyliński \\ Wydział Filozofii Chrześcijańskiej \\ Uniwersytet Kardynała Stefana Wyszyńskiego \\ ul. Wóycickiego 1/3, 01-938 Warszawa, a.kobylinski@uksw.edu.pl
}

\section{Streszczenie}

Głównym celem artykułu jest analiza zjawiska pedofilii w Holandii oraz prezentacja najważniejszych aspektów etycznych i prawnych wykorzystywania seksualnego dzieci. Wydaje się, że w kraju tulipanów pojawiło się swego rodzaju sprzężenie zwrotne: z jednej strony rewolucja seksualna lat sześćdziesiątych XX wieku, proces głębokiej sekularyzacji społeczeństwa holenderskiego i narodziny nowej moralności stworzyły podatny grunt dla rozwoju zjawiska pedofilii, z drugiej - dramat seksualnego wykorzystywania nieletnich przyczynił się do jeszcze głębszego kryzysu tradycyjnego rozumienia moralności i religii, powodując stopniowy rozpad Kościoła katolickiego i innych wyznań chrześcijańskich. Bardzo wiele cennych informacji na temat pedofilii w Holandii zawiera specjalny raport, opublikowany w 2011 r. przez komisję śledczą Wima Deetmana. Dramat seksualnego wykorzystywania dzieci w tym kraju jest niewielką częścią wielkiego zjawiska w skali globalnej. Kluczową kwestią w sporze dotyczącym wykorzystywania seksualnego dzieci jest rzetelna argumentacja filozoficzna, która zwraca uwagę na zło moralne relacji seksualnych między osobami dorosłymi i dziećmi.

\section{Słowa kluczowe}

pedofilia, wykorzystywanie seksualne dzieci, pedopornografia, rewolucja seksualna, sekularyzacja, prawa dzieci, orientacja seksualna

\section{Wprowadzenie}

Bolesny i wstydliwy fenomen molestowania seksualnego dzieci może przybierać różne formy. Badania socjologiczne prowadzone w wielu krajach pokazują, że osoby nieletnie są krzywdzone najczęściej w kręgu swoich krewnych i znajomych. Wśród wielu różnych form tego zjawiska należy wskazać m.in. pornografię dziecięcą, niewłaściwy dotyk, tzw. inne czynności seksualne, cyberpedofilię, czy tzw. turystykę seksualną, która oznacza m.in. wykorzystywanie seksualne dzieci w biednych krajach Azji czy
Ameryki Południowej przez bogatych ludzi Zachodu.

Jednym z krajów dotkniętych bardzo głęboko dramatem pedofilii jest Holandia. Specyfiką kraju tulipanów jest w tej materii nie tyle skala ofiar czynów pedofilskich, ile funkcjonowanie bardzo wpływowych środowisk politycznych i społecznych, które dążą do legalizacji pedofilii. W 2000 r. Holandia była pierwszym krajem na świecie, w którym zalegalizowano eutanazję. W niektórych komentarzach mówiono wówczas o tzw. rewolucji holenderskiej - rewolucji 
obyczajowej, polegającej zasadniczo na tworzeniu prawa sankcjonującego przemiany moralne w społeczeństwach zachodnich, które dokonały się w dużym stopniu pod wpływem rewolucji seksualnej $1968 \mathrm{r}$. Postulat legalizacji pedofilii jest kolejnym etapem rozwoju tak rozumianej rewolucji holenderskiej.

W języku polskim są dostępne różnego rodzaju materiały publicystyczne dotyczące zjawiska pedofilii w Holandii, Europie czy na świecie. Niestety, ciągle brakuje rzetelnych opracowań naukowych tego zagadnienia. W wielu innych krajach seksualne wykorzystywanie dzieci jest przedmiotem szeroko zakrojonych badań antropologicznych, etycznych, bioetycznych, socjologicznych czy psychologicznych. Przykładem takich diagnoz i analiz może być najnowsza książka z 2015 r. Stephena Kershnara, profesora filozofii w Uniwersytecie Stanowym w Nowym Jorku, Pedophilia and Adult Child Sex: A Philosophical Analysis („Pedofilia oraz seks osób dorosłych i dzieci: Analiza filozoficzna"). Studium stanowi pogłębioną analizę różnych form seksualnego molestowania dzieci (por. Kershnar 2015).

Badacz z Nowego Jorku szuka odpowiedzi na kilka trudnych pytań: W jakim stopniu czyny pedofilskie są przejawem choroby? W jakich przypadkach można mówić nie o jednostce chorobowej, ale jedynie o złych zachowaniach czy skłonnościach, które podlegają kontroli rozumu i wolnej woli człowieka? Jak oceniać moralnie różne formy wykorzystywania seksualnego dzieci i jakie rozwiązania prawne powinny być przyjęte dla lepszej ochrony osób nieletnich?

Pytania postawione przez Stephena Kershnara dotyczą nie tylko społeczeństwa amerykańskiego, ale odnoszą się do problemu pedofilii w wymiarze globalnym. Celem tego artykułu jest analiza przyczyn i specyfiki seksualnego wykorzystywania dzieci w Holandii oraz ukazanie najważniejszych aspektów etycznych tego dramatycznego zjawiska.

\section{Sekularyzacja społeczeństwa holenderskiego i nowa moralność}

Jednym z „ojców założycieli” rewolucji obyczajowej i politycznym mentorem rewolty studenckiej 1968 r. był filozof i socjolog niemiecko-amerykański żydowskiego pochodzenia Herbert Marcuse (1898-1979). Marcuse, jako jeden z najbardziej znanych przedstawicieli Szkoły Frankfurckiej, nakreślił w swoich dziełach wizję nowego społeczeństwa, zbudowanego na zgliszczach społeczeństwa mieszczańskiego, w którym dokona się reinterpretacja tradycyjnej moralności (por. Kobyliński 1994; Marcuse 1998).

„Ten siedemdziesięciolatek - pisze Adam Krzemiński - reprezentował wszystko, o czym marzyli studenci. Jako żydowski emigrant nie miał nic wspólnego z nazistowskimi biografiami ich rodziców, a zarazem wojskowym tonem udzielał politycznych wskazówek, jak stworzyć Nowego Człowieka - łącząc walkę polityczną z wyzwoleniem seksualnym. To pod jego wpływem zaczęto mówić o froncie seksualnym. Ideałem Marcusego była wielka jedność form życia, «regresja», w której indywidualne konflikty między mężczyznami i kobietami rozpłynęłyby się w ciepełku solidarnego kolektywu. Jego książka Eros i cywilizacja była szeroko zakrojoną próbą przezwyciężania tez Freuda, który twierdził, że nie ma cywilizacji bez represjonowania popędu. Nie, odpowiadał Marcuse, istnieje wprawdzie pewna marża represji niezbędnej dla zachowania gatunku, ale większość to ucisk dodatkowy, służący jedynie określonej władzy historycznej. W kulturze, która nie jest chora, eros może być siłą wyzwalającą i jednoczącą. Możliwy jest raj na Ziemi" (Krzemiński 2005: 31).

Jednym z najbardziej znanych w Europie działaczy frontu seksualnego był Daniel Cohn-Bendit - polityk niemiecki, który urodził się we Francji w rodzinie niemiecko-żydowskiej (por. Zechenter 2008). Był on jednym z przywódców ruchu studenckiego we Francji i paryskiego Maja 68. Zyskał wówczas przydomek „Czerwony Dany”. W 1968 r. został wydalony z Francji i zamieszkał 
w Niemczech. W 2001 r. niemiecka dziennikarka Bettina Röhl oskarżyła go publicznie o pedofilię na podstawie autocytatów z jego autobiograficznej książki z 1975 r. Wielki Bazar. W tej publikacji Daniel Cohn-Bendit opisał swoje osobiste doświadczenia z seksualnością dzieci, gdy w latach 1972-1974 pracował jako wychowawca w tzw. przedszkolu alternatywnym we Frankfurcie nad Menem. "Czerwony Dany” wyznał szczerze w swojej książce, że jego "ciągły flirt z dziećmi szybko przyjął charakter erotyczny”.

Zwolennicy nowej moralności Herberta Marcusego - żyjąc często jako komunardzi w zakładanych przez siebie komunach byli przekonani, że „seksualność dziecka jest czymś wspaniałym" oraz prowadzili różnego rodzaju „badania” dotyczące przeżywania sfery erotycznej przez ludzi dorosłych i osoby nieletnie. To, co dziś uznajemy powszechnie za pedofilię, traktowano wówczas jako tzw. odblokowanie popędów. „Wzorem miały być izraelskie kibuce, Poemat pedagogiczny Makarenki, a także opowieść Anny Freud z sierocińca dla dzieci z Teresina. Te dzieci nie miały zabawek, żyły w grupie, ignorowały dorosłych, ale dla siebie nawzajem były czułe. Każde się onanizowało, drapało aż do krwi, ale Anna Freud wyraźnie pisała: «Nie były zaniedbane, poszkodowane czy psychotyczne. Znalazły inną możliwość wyżycia swego libido, to pomogło im uporać się z lękami». Upiorna, prowokacyjna wizja: żydowskie sieroty $\mathrm{z}$ kacetu jako ideał wychowania dla niemieckich komunardów 1968 r., a neurotyczne zachowania - wzorcem wyzwolenia" (Krzemiński 2005: 32).

Wydaje się, że w przypadku Holandii można mówić o częściowej realizacji projektu nowego społeczeństwa Herberta Marcusego, w którym tradycyjna obyczajowość zostaje zastąpiona ideami skrajnego libertynizmu moralnego. W jaki sposób powstało w kraju tulipanów nowe społeczeństwo? Kiedy Holendrzy odrzucili tradycyjną moralność na rzecz nowych zasad etycznych? Pół wieku temu Holandia należała do grupy niezwykle religijnych i konserwatywnych społeczeństw Europy. Prawie wszyscy mieszkańcy tego kraju byli albo praktykującymi katolikami, albo praktykującymi protestantami. Pod koniec lat 50. xx wieku ok. 90\% obywateli Holandii poważnie traktowało swoją religię i było przywiązanych do tradycyjnej moralności chrześcijańskiej.

W połowie ubiegłego stulecia niezwykle ważną rolę w społeczeństwie holenderskim odgrywał Kościół katolicki, który posiadał rozbudowany system szkolny, silne media, partię polityczną i związek zawodowy. Niestety, w ostatnich latach można mówić o powolnym umieraniu chrześcijaństwa holenderskiego, rozpadzie tradycyjnego rozumienia norm etycznych i narodzinach nowej moralności. Wymowną egzemplifikacją tego procesu było poparcie społeczne na poziomie $92 \%$ dla ustawy legalizującej eutanazję $\mathrm{w} 2000 \mathrm{r}$.

Obecnie Holandia liczy 17 milionów mieszkańców. 25\% społeczeństwa stanowią chrześcijanie (11.7\% katolicy, 8.6\% członkowie Protestanckiego Kościoła Holandii - Protestantse Kerk in Nederland, 4.2\% wyznawcy innych denominacji chrześcijańskich). $5 \%$ społeczeństwa holenderskiego to muzułmanie, $2 \%$ stanowią przedstawiciele hinduizmu i buddyzmu. Wśród katolików zachowuje praktyki religijne jedynie 5\% wyznawców. Jeszcze niższy poziom praktyk religijnych występuje wśród protestantów. Aż 68\% Holendrów nie ma żadnego związku z jakąkolwiek religią. Wśród ateistów i agnostyków wyróżnia się ostatnio nową grupę zwolenników „jetsizmu” bądź "cosizmu” (ang. Ietsism, Somethingism; nl. Ietsisme), który oznacza bliżej niekreślone przekonanie o istnieniu między niebem a ziemią jakiejś nieznanej siły transcendentnej, której nie należy nazywać Bogiem.

W ciągu ostatnich 50 lat Holandia stała się jednym z najbardziej zsekularyzowanych społeczeństw na świecie - kraj tulipanów przeszedł w niezwykle krótkim czasie długą droge od tradycyjnej moralności chrześcijańskiej do nowej moralności w duchu liderów rewolucji seksualnej 1968 r. Holendrzy stali się zaprzeczeniem tego, kim byli w niedawnej przeszłości. Gdy chodzi o kręgi 
katolickie, każdego roku występuje z Kościoła jako instytucji ok. 18 tys. wiernych. Do 2020 r. przewiduje się w kraju tulipanów zamknięcie jednej trzeciej katolickich świątyń, które są sukcesywnie zamieniane na magazyny, restauracje, pensjonaty czy sale do uprawiania skateboardu. Warto pamiętać, że wspólnoty protestanckie w Holandii zderzyły się po raz pierwszy z procesem sekularyzacji już w pierwszej połowie xx wieku, natomiast do środowisk katolickich fala sekularyzacji dotarła w latach 6o. ubiegłego stulecia.

„Niektórzy mówią - zauważa włoski dziennikarz Matteo Matzuzzi - że aby zrozumieć dzisiaj Holandię, ateistyczną, świecką, wielokulturową i przyjazną, trzeba sięgnąć pamięcią do lat siedemdziesiątych $\mathrm{xx}$ wieku, kiedy na boiskach Europy szalał legendarny Ajax Amsterdam Rinusa Michelsa - klub piłkarski nazywany «Mechaniczną pomarańczą», pomnik narodowy Holandii [...]. To była pierwsza libertyńska drużyna piłki nożnej w historii, która odrzuciła tak modne dzisiaj kodeksy etyczne lub pseudo-etyczne" (Web-04).

Ajax Amsterdam złamał jako pierwszy w historii sportu zakaz prawie sakralny, dotyczący powstrzymywania się zawodników od relacji seksualnych przed rozgrywanymi meczami. Podczas gdy inne drużyny poświęcały długie tygodnie na treningi i studiowanie taktyki przeciwników, piłkarze Ajaxu Amsterdam spędzali czas na rozrywce. Byli na tyle aroganccy, że pozwalali sobie na odrzucenie wszystkich możliwych zasad moralnych, uznawanych do tej pory za święte i normujące naszą rzeczywistość. Zawodnicy Ajaxu Amsterdam byli pierwszymi, którzy zaczęli przywozić na swoje zgrupowania sportowe żony, narzeczone i kochanki. Mogli robić to, na co mieli ochotę. Wcielali w życie zasady nowej moralności rewolucji obyczajowej $1968 \mathrm{r}$.

\section{Zaburzenie czy orientacja seksualna?}

W ostatnich latach pedofilia stała się zjawiskiem masowym w wymiarze globalnym. Nie jest już tylko zachowaniem typowym dla niektórych maniaków seksualnych, ale przekształca się coraz bardziej w prawdziwą przestępczość zorganizowaną na skalę światową. Najczęściej współczesny pedofil nie przypomina „potwora”, którego można łatwo odróżnić od innych osób. Zwykle jest to osoba pozornie normalna, czasami zajmująca wysoką pozycję społeczną, przebywająca lub pracująca wśród dzieci, która utożsamia się z figurą ojca, matki, dziadka.

Warto podkreślić, że rozwój Internetu zmienił radykalnie życie pedofilów. Dzięki potężnemu medium mogą oni dzisiaj nie tylko korzystać z pedopornografii, ale tworzą także własną „kulturę”, której celem jest przekonanie opinii publicznej, że mają prawo do wolnej ekspresji własnej erotyki i relacji seksualnych z dziećmi. Coraz częściej słyszymy dzisiaj, że istnieje bardzo silne lobby pedofilów, do którego należą przedstawiciele świata polityki, kultury, biznesu. Pedofilia to nie tylko wykorzystywanie seksualne dzieci, ale także promowanie pewnego stylu życia i wywieranie nacisku na opinię publiczną, aby zachowania erotyczne pedofilów traktować jako jedną z normalnych skłonności seksualnych człowieka (por. Bellaspiga 2016).

Warto zauważyć, że obecnie podejmuje się różne próby leczenia pedofilii. Jedną z metod jest terapia hormonalna, która polega na obniżeniu poziomu testosteronu - męskiego hormonu płciowego. Natomiast druga metoda to leczenie psychiatryczne, w którym pedofilia jest traktowana jako obsesja i zaburzenie uczuciowości. Jednak największym problemem w leczeniu tego zaburzenia jest brak współpracy ze strony pedofila, który nie uważa siebie za osobę chorą i potrzebującą pomocy.

Jak można określić istotę pedofilii? $\mathrm{Na}$ czym polega to jakże poważne i niebezpieczne zaburzenie seksualne? Pedofilia (gr. pais - chłopiec, philia - miłość, przyjaźń) jest anomalią psychoseksualną osoby dorosłej, która czuje pociąg seksualny wobec dzieci. Pedofil chce być dzieckiem jak inne dzieci. Odrzuca świat dorosłych i pragnie żyć w świecie nieletnich, bardzo często 
cierpi z powodu patologii narcyzmu. „Pedofilia - twierdzi Pier Davide Guenzi - może oznaczać każdy rodzaj trwałego i powracającego zainteresowania seksualnego (nawet na poziomie fantazji, zarówno na tle heteroseksualnym jak i homoseksualnym, w formie kazirodczej lub nie) ze strony dorosłych wobec dzieci (pedofilia w ścisłym tego słowa znaczeniu) lub wobec chłopców w pierwszym okresie pokwitania (pedoefebofilia), i jako taka może być zaliczona do parafilii konkretnej anomalii seksualności osób dorosłych" (Guenzi 2004: 843).

Warto podkreślić, że pedofil jest zainteresowany dziećmi poniżej 11 roku życia. Od pedofilii należy odróżnić efebofilię, która dotyczy dzieci w starszym wieku. Prof. Tonino Cantelmi - znany psychiatra i psychoterapeuta, przewodniczący Włoskiego Stowarzyszenia Psychologów i Psychiatrów Katolickich (Associazione Italiana Psicologi e Psichiatri Cattolici) definiuje efebofilię jako pociąg seksualny do dojrzewających chłopców w wieku od 12 do 17 lat. Należy podkreślić, że pedofilia jako zaburzenie - podobnie jak efebofilia - nie pozbawia człowieka „zdolności rozumienia i chcenia", dlatego od strony etycznej i prawnej pedofil ponosi odpowiedzialność za swoje czyny.

W 2013 r. Amerykańskie Towarzystwo Psychiatryczne (American Psychiatric Association) opublikowało piątą edycję klasyfikacji zaburzeń psychicznych (Diagnostic and Statistical Manual of Mental Disorders, DSM-5). W tym dokumencie, mającym wielkie znaczenia dla psychologii i psychiatrii na całym świecie, pedofilia została sklasyfikowana jako jedna z orientacji seksualnych. Po zdecydowanych protestach wielu środowisk, Amerykańskie Towarzystwo Psychiatryczne wycofało się ze swojej wcześniejszej oceny pedofilii. Władze tej organizacji przyznały w specjalnym oświadczeniu z 30 listopada 2013 r., że określenie pedofilii jako orientacji seksualnej było błędem. Orientacja seksualna nie jest terminem używanym w kryteriach diagnozy zaburzenia pedofilskiego. Amerykańskie Towarzystwo Psychiatryczne zapewniło, że rozumie czyny pedofilskie jako parafilię, czyli zaburzenie preferencji seksualnych, a nie jako orientację seksualną. Ten błąd został poprawiony w elektronicznej wersji piątej edycji klasyfikacji zaburzeń psychicznych.

W niektórych krajach kolejnym etapem rewolucji obyczajowej - po legalizacji tzw. małżeństw gejowskich i przyznaniu im prawa do adopcji dzieci - mogą być dążenia do prawnego usankcjonowania pedofilii (por. Web-o6). Coraz częściej pedofilia jest ukazywana nie jako przestępstwo, ale jako jedna z orientacji seksualnych człowieka. Niebezpieczne sygnały płyną z wielu państw. W 2013 r. ożywioną dyskusję w kraju nad Tybrem wywołał wyrok Najwyższego Sądu Kasacyjnego (Suprema Corte di Cassazione), który uchylił wyrok skazujący sądu niższej instancji w sprawie dotyczącej wielokrotnych pełnych relacji seksualnych mężczyzny w wieku 6o lat z 11. dziewczyną. W uzasadnieniu wyroku Najwyższy Sąd Kasacyjny we Włoszech wskazał na „niewielką szkodliwość czynu" oraz zwrócił uwagę na relację miłosną istniejącą między sprawcą i ofiarą - małoletnia dziewczyna była rzekomo „zakochana” w 6o. letnim mężczyźnie (por. Web-05).

W niektórych krajach toczy się debata publiczna dotycząca obniżenia dolnej granicy wieku, gdy chodzi o przyzwolenie na relacje seksualne. Przykładem może być Wielka Brytania - kilka lat temu Barbara Hewson, adwokatka angielska znana ze swego zaangażowania w walce o prawa obywatelskie, zgłosiła postulat obniżenia dolnej granicy do 13 lat. Barbara Hewson domaga się także redefinicji pojęcia "seksualnego wykorzystywania osób nieletnich". Jej zdaniem, klasyfikacja naukowa zachowań seksualnych powinna abstrahować od kryteriów o charakterze moralnym czy prawnym. Relacje seksualne za obopólną zgodą między osobami nieletnimi i dorosłymi, między osobami dojrzewającymi i dziećmi powinny być opisywane w kategoriach bardziej pozytywnych jako „seks między dorosłymi i nieletnimi" (adult-minor sex). 
14 lutego 2013 r. w Queen's University w kanadyjskim mieście Kingston, w prowincji Ontario, miała miejsce publiczna debata, w której wzięło udział dwóch znanych naukowców: Vernon Quinsey - emerytowany profesor psychologii tej uczelni, Hubert Van Gijseghem - emerytowany profesor psychologii z Université de Montreal. Obydwaj dyskutanci przedstawili argumenty "naukowe” w obronie pedofilii. Ich zdaniem, pedofilia powinna być postrzegana jako orientacja seksualna na wzór orientacji heteroseksualnej czy homoseksualnej. Dwaj znani kanadyjscy psychologowie stwierdzili publicznie, że pedofilia stanowi jedną z wielu naturalnych form ludzkiej seksualności (por. Web-05).

Współczesne spory dotyczące pedofilii, macierzyństwa zastępczego czy orientacji seksualnej wskazują na coraz większą trudność wypracowania spójnej oceny moralnej różnych nowych zjawisk naszego życia społecznego i znalezienia odpowiednich regulacji prawnych. Egzemplifikacją tego problemu może być legalizacją tzw. małżeństw gejowskich we Włoszech w pierwszej połowie 2016 r. W kontekście uchwalenia nowego prawa powstał problem stosowania zasady sprzeciwu sumienia przez pracowników Urzędów Stanu Cywilnego, którzy przewodniczą w ceremoniach zawierania ślubów w wersji cywilnej (por. Web-o3). Setki burmistrzów, wójtów i urzędników, którzy nie akceptują związków homoseksualnych, domagają się uszanowania ich przekonań światopoglądowych. Wielu komentatorów zwraca uwagę na konieczność regulacji prawnych w tej materii na wzór klauzuli sumienia w świecie pracowników służby zdrowia.

\section{Działalność organizacji pedofilskich}

Na całym świecie działa obecnie kilkaset różnego rodzaju organizacji pedofilskich. Głoszą one hasła walki o „wyzwolenie” dzieci z ograniczeń, które narzuca im rzekomo rodzina oraz społeczeństwo. Istotą tego „wyzwolenia” powinno być wyzwolenie seksualne oraz uznanie prawa dziecka do własnej ekspresji seksualnej - także w relacji do osób dorosłych. Największa tego rodzaju organizacja o charakterze międzynarodowym to „International Pedophile and Child Emancipation". W Australii funkcjonowała w ostatnich latach m.in. organizacja pedofilska o nazwie „Boy Lovers and Zucchini Eaters". Jedną z najbardziej wpływowych tego rodzaju organizacji europejskich była z kolei „Danish Pedophilie Association”, która działała legalnie w latach 1985-2004. Strona internetowa tego stowarzyszenia funkcjonuje nadal i jest obsługiwana przez grupę jego byłych członków.

Gdy chodzi natomiast o Holandię, warto przypomnieć, że w latach 2006-2010 istniało w tym kraju legalnie działające ugrupowanie polityczne o nazwie „Partia na rzecz Miłości Bliźniego, Wolności i Różnorodności” (Partij voor Naastenliefde, Vrijheid $\mathcal{E}$ Diversiteit - w skrócie PNVD), które chciało wejść do parlamentu, aby walczyć na drodze parlamentarnej o prawa pedofilów. Partia została założona przez trzech mężczyzn, którzy uważali samych siebie za pedofilów. Tylko ci trzej założyciele byli jawnymi członkami partii, reszta działaczy pozostawała anonimowa. Dlaczego akurat tylko trzech jawnych działaczy? To specyfika prawa holenderskiego. Taka liczba nieanonimowych osób jest niezbędna do formalnego założenia partii politycznej w Holandii. To ugrupowanie było powszechnie określane w holenderskiej domenie publicznej jako „pedopartia” (pedopartij). Mottem organizacji uczyniono łacińską maksymę sapere aude (sic!). Przedstawiciele tej partii nie weszli do parlamentu w Hadze, ponieważ w wyborach parlamentarnych partia nie przekroczyła wymaganego progu wyborczego.

Jakie były najważniejsze postulaty polityczne tego ugrupowania? „Pedopartia” domagała się legalizacji pornografii dziecięcej i obniżenia granicy wieku legalnego współżycia seksualnego z 16 do 12 lat. Co więcej, działacze tej partii uważali, że w dalszej perspektywie jakakolwiek granica wieku powinna być całkowicie zniesiona. PNVD występowała przeciw projektom delegalizacji zoofilii, która w opinii członków 
i sympatyków tej partii powinna być w pełni legalna, o ile nie wiąże się to z nadmiernym wyeksploatowaniem czy maltretowaniem zwierzęcia. Działacze „pedopartii” domagali się także zmniejszenia wieku, w którym można występować w filmach pornograficznych oraz wykonywać „zawód” prostytutki do 16 lat. Program PNVD przewidywał również zlikwidowanie instytucji małżeństwa oraz możliwość legalizacji miękkich narkotyków dla osób od 12. roku życia, a od 16. lat również twardych.

Działacze PNVD byli powiązani z holenderską organizacją pedofilską „Sticthing Martijn”. W 2014 r. dokonano w kraju tulipanów delegalizacji tego stowarzyszenia, które powstało w 1982 r. - funkcjonowało ono zgodnie $\mathrm{z}$ holenderskim prawem przez 32 lata. Przez cały czas swojej publicznej działalności organizacja dążyła do zniesienia barier prawnych, zabraniających dorosłym nawiązywania relacji seksualnych z nieletnimi. Stowarzyszenie wydawało kwartalnik „OK”, który promował nawiązywanie kontaktów seksualnych osób dorosłych z dziećmi za zgodą ich rodziców.

W kwietniu 2014 r. Holenderski Sąd Kasacyjny w Hadze uznał, że stowarzyszenie promujące pedofilię stanowi zagrożenie dla bezpieczeństwa dzieci i porządku publicznego. W ten sposób został uchylony wyrok Sądu Apelacyjnego w Arnhem-Leeuwarden z kwietnia 2013 r., który stanął w obronie tej organizacji, powołując się na zasadę wolności wypowiedzi i prawo do stowarzyszania się. Wyrok sądu drugiej instancji stanowił uchylenie wyroku sądu pierwszej instancji, który dokonał delegalizacji organizacji pedofilskiej „Sticthing Martijn”.

Po wyroku Sądu Kasacyjnego z kwietnia 2014 r. członkowie PNVD nie dali jednak za wygraną - odwołali się do Europejskiego Trybunału Praw Człowieka w Strasburgu. W uzasadnieniu swojego stanowiska stwierdzili, że delegalizacja ich organizacji - po kilkudziesięciu latach jawnej działalności - narusza konstytucyjne prawo do wolności wypowiedzi. W lutym 2015 r. Trybunał w Strasburgu odrzucił skargę tego stowarzyszenia, powodując tym samym jego definitywną delegalizację i zamykając ostatecznie wieloletnią batalię sądową w tej sprawie.

\section{Dramat Kościola katolickiego w Holandii}

Główne idee rewolucji obyczajowej 1968 r. ukształtowały w ostatnich dziesięcioleciach mentalność znakomitej większości mieszkańców Holandii. Niestety, wizja nowej moralności w duchu Herberta Marcusego została w dużym stopniu przyjęta także przez katolików i protestantów zamieszkujących ten kraj. W drugiej połowie lat 6o. ubiegłego wieku spotkały się ze sobą w społeczeństwie holenderskim, ale także w wielu innych państwach zachodnich, dwa silne prądy światopoglądowe: z jednej strony, rewolucja seksualna i rewolta studencka, z drugiej - głębokie reformy w Kościele katolickim po Soborze Watykańskim II (1962-1965). Połączenie tych dwóch nurtów doprowadziło w Holandii do powstania nowej formy katolicyzmu w wersji ultrapostępowej, która stanowiła radykalne odejście od tradycyjnego rozumienia religii i moralności (por. Kelly 2015).

Dużą rolę w procesie modernizacji świadomości moralnej mieszkańców kraju tulipanów odegrał tzw. Katechizm holenderski, wydany w Utrechcie w 1966 r., który został zredagowany i zaaprobowany przez władze Kościoła katolickiego w Holandii. Jednym z głównych twórców tego dzieła był bardzo postępowy teolog dominikański Edward Schillebeeckx (1914-2009). Autorzy tego podręcznika doktrynalnego dla katolików zaproponowali uwspółcześnienie tradycyjnego nauczania katolickiego, kładąc szczególny nacisk na rewizję wielu podstawowych prawd moralnych dotyczących m.in. istoty ludzkiej miłości czy seksualności oraz rozumienia małżeństwa i rodziny (por. Dreissen 1968). Katechizm holenderski został przetłumaczony na wiele języków świata. Został sprzedany w milionach egzemplarzy.

Katolicyzm w wersji ultrapostępowej przestał pełnić funkcję krytyczną w stosunku 
do radykalnych zmian zachodzących w społeczeństwie holenderskim. Niestety, w ostatnich dziesięcioleciach katolicy i protestanci - podobnie jak w wielu innych krajach - prawie w ogóle nie zabierali głosu w debacie publicznej, gdy chodzi o rozwój zjawiska pedofilii (por. Townsend 2013; McGillion, Grace 2014; Salter 2014; Sguotti 2015). W związku z tym można powiedzieć, że w Holandii doszło w tej sprawie do ogólnonarodowej zmowy milczenia: partie polityczne, organizacje pozarządowe, stowarzyszenia, kościoły i związki wyznaniowe zachowywały daleko idącą wstrzemięźliwość, gdy chodzi o ocenę moralną seksualnego wykorzystywania osób nieletnich.

Badania fenomenu molestowania seksualnego dzieci wyraźnie pokazują, że jego siła tkwi przede wszystkim w społecznym milczeniu, które generuje. Coraz częściej na określenie tego rodzaju wyparcia problemu ze świadomości publicznej używa się włoskiego pojęcia „omertà”, które oznacza zmowę milczenia. Takie dyscypliny naukowe jak psychologia, psychiatria, socjologia czy prawo wykonały w ostatnich latach ogromną pracę, aby opisać i zdiagnozować zjawisko pedofilii, ale „wydaje się, że ciągle jest za mało światła rzuconego na zjawisko, które pod pewnymi względami pozostaje wciąż nierozpoznane" (Di Noto 2002: 5-6).

W wielu krajach zmowa milczenia wokół wykorzystywania seksualnego dzieci trwa nadal - jakby nie obowiązywała Międzynarodowa Konwencja o Prawach Dziecka, przyjęta przez Zgromadzenie Ogólne ONZ w 1989 r. W artykule 34. tego ważnego dokumentu czytamy, że władze państwowe mają obowiązek ochrony dzieci przed wszelkimi formami wyzysku seksualnego i nadużyć seksualnych. Dla osiagnnięcia tych celów należy „podjąć w szczególności wszelkie właściwe kroki o zasięgu krajowym, dwustronnym oraz wielostronnym dla przeciwdziałania: a) nakłanianiu lub zmuszaniu dziecka do jakichkolwiek nielegalnych działań seksualnych; b) wykorzystywaniu dzieci do prostytucji lub innych nielegalnych praktyk seksualnych; c) wykorzystywaniu dzieci w pornograficznych przedstawieniach i materiałach".

W Holandii niektóre ofiary molestowania seksualnego przerwały milczenie w $2010 \mathrm{r}$. na fali ujawnianych skandali pedofilskich w Kościele katolickim w UsA, Australii, Belgii, Austrii czy Irlandii. Niestety, uwaga opinii publicznej skupiła się zasadniczo na Kościele katolickim, zakrywając zasłoną milczenia odpowiedzialność w tej materii innych kościołów i związków wyznaniowych, organizacji społecznych czy partii politycznych. W holenderskiej dyskusji społecznej na temat pedofilii w 2010 r. całkowicie pominięto sprawę kluczową, czyli wpływ rewolucji seksualnej 1968 r. na narodziny nowego społeczeństwa i nowej moralności. Problem wykorzystywania seksualnego dzieci zaczął być dostrzegany częściowo w społeczeństwie holenderskim w latach 8o. ubiegłego wieku. Niestety, skandal wybuchł dopiero w ostatnich latach, ponieważ przez długie dziesięciolecia molestowanie seksualne dzieci było tematem tabu w domenie publicznej (por. Introvigne, Marchesini 2014).

Nie oznacza to bynajmniej, że w kraju tulipanów nie podejmowano żadnych działań, które służyłyby ograniczeniu tego zjawiska. Od 1985 r. fenomen pedofilii stał się przedmiotem zainteresowania działaczy różnych partii politycznych. Gdy przeprowadzone wówczas badania socjologiczne pokazały, że znacząca liczba kobiet i dziewcząt stała się ofiarami wykorzystywania seksualnego, rząd przyjął szereg środków zaradczych. Wzrastające zainteresowanie tym problemem skłoniło w 1992 r. władze w Hadze do reformy ustawodawstwa dotyczącego przestępstw seksualnych. Zmiany w prawie karnym zapewniły lepszą ochronę nieletnich przed niechcianym kontaktem seksualnym. Od tego czasu ochrona nieletnich przed wszelkimi formami wykorzystywania seksualnego stała się celem działań politycznych na poziomie narodowym i międzynarodowym, co znalazło odzwierciedlenie w dyrektywach Unii Europejskiej i wyrokach Europejskiego Trybunału Praw Człowieka. 
W Kościele katolickim w Holandii pierwsze analizy tego zjawiska koncentrowały się na molestowaniu seksualnym w relacjach zależności służbowej czy rodzinnej. Najczęściej chodziło o kazirodztwo czy inne formy wykorzystywania seksualnego w środowisku rodzinnym. Na początku la 9o. zostały wypracowane pierwsze instrukcje dotyczące opieki duszpasterskiej w takich sytuacjach. W 1995 r. została powołana do życia przez władze kościelne organizacja Hulp \& Recht (Pomoc i Sprawiedliwość), której celem było rozpatrywanie skarg dotyczących molestowania seksualnego w instytucjach należących do Kościoła katolickiego. W 1998 r. zostały przyjęte zasady regulujące kwestię zgłaszania przez władze kościelne przypadków pedofilii odpowiednim organom śledczym państwa holenderskiego. W 2007 r. procedura rozpatrywania skarg dotyczących wykorzystywania seksualnego została rozszerzona na wszystkie kategorie osób, które wykonywały jakąkolwiek pracę, odpłatną czy nieodpłatną, w różnego rodzaju instytucjach należących do Kościoła katolickiego.

W 2010 r., po wybuchu skandalu medialnego dotyczącego pedofilii, Konferencja Biskupów Holenderskich i Holenderska Konferencja Przełożonych Zakonnych powołały wspólnie specjalną komisję śledczą, niezależną od władz kościelnych, do zbadania przypadków pedofilii w instytucjach Kościoła katolickiego funkcjonujących w państwie holenderskim oraz na terenach związanych politycznie z władzami w Hadze, np. na wyspach Aruba i Curacao, należących do Antyli Holenderskich. Na czele komisji stanął znany i doświadczony polityk chadecki Wim Deetman - obecnie członek Rady Państwa, wcześniej burmistrz Hagi, przewodniczący izby niższej parlamentu holenderskiego, minister Edukacji i Nauki. Pozostałych pięciu członków komisji śledczej to Nel Draijer, Pieter Kalbfleisch, Harald Merckelbach, Marit Monteiro i Gerard de Vries.

Sześcioosobowa Komisja Deetmana pracowała od lata 2010 do wiosny $2011 \mathrm{r}$.
Członkowie Komisji przestudiowali 1,8 tys. skarg, które zostały skierowane bezpośrednio do nich. Poddali analizie także streszczenia zeznań wielu innych osób, które skierowały swoje skargi do organizacji Hulp \& Recht w latach 1995-2010. Jedną z form pracy Komisji było także badanie ankietowe na reprezentatywnej grupie obywateli holenderskich, którzy w 2010 r. ukończyli 40 lat. Komisja otrzymała 34 tys. 234 wypełnione kwestionariusze. „Według tego badania, co dziesiąta osoba mieszkająca w Holandii, przed ukończeniem 18. roku życia, została poddana wbrew swej woli różnym działaniom seksualnym z osobą dorosłą, która nie jest członkiem jej rodziny" (Web-o2: 8).

W 2011 r. Komisja Deetmana opublikowała specjalny raport w wersji papierowej liczący 864 strony (por. Deetman 2011). Dokument jest też dostępny w wersji elektronicznej w pełnej wersji w języku niderlandzkim, natomiast $\mathrm{w}$ języku angielskim została przygotowana jego wersja skrócona pt. Sexual abuse of minors in the Roman Catholic Church (por. Web-02). Raport został powszechnie uznany za bardzo przejrzysty i niezwykle rzetelny. Taką opinię wyraził m.in. kard. Willem Jacobus Eijk - arcybiskup Utrechtu i prymas Holandii.

Raport Komisji Deetmana stwierdza, że w Holandii w latach 1945-2010 było molestowanych seksualnie kilkadziesiąt tysięcy dzieci w różnego rodzaju instytucjach katolickich: szkołach, internatach, zakonach, seminariach duchownych, stowarzyszeniach i organizacjach kościelnych. Przez wiele dziesięcioleci całkowicie tuszowano to dramatyczne zjawisko - jak w wielu innych instytucjach holenderskich - ponieważ takie było przyzwolenie społeczne. Do molestowania dzieci dochodziło także w wielu innych instytucjach publicznych niezwiązanych z Kościołem katolickim. Jak wynika z Raportu z 2011 r., ofiarą molestowania seksualnego w latach 1945-2010 w wielu różnych instytucjach państwowych, społecznych i kościelnych oraz w środowisku rodzinnym padło co dziesiąte holenderskie dziecko. 
Komisja Deetmana zidentyfikowała ok. 80 o pracowników Kościoła katolickiego (księży, zakonników, ludzi świeckich), odpowiedzialnych za wykorzystywanie seksualne dzieci. Z tej grupy oskarżonych żyło w 2011 r. już tylko 105 osób. Różnego rodzaju czynności śledcze potwierdziły m.in. oskarżenia o molestowanie seksualne dzieci i wspieranie organizacji pedofilskich wobec bp. Philippa Bära (1928-), który kierował diecezją Rotterdam w latach 1983-1993. Komisja zachowała anonimizację danych personalnych sprawców, co stanowi praktykę powszechnie przyjętą w Holandii. Dane osobowe sprawców zostały podane tylko w tych przypadkach, gdy pełnili oni funkcje społeczne czy państwowe lub gdy oskarżenia miały już wcześniej charakter publiczny i znana była ich tożsamość.

Komisja zbadała korelację między częstotliwością przypadków pedofilii a przebywaniem dzieci w różnego rodzaju instytucjach państwowych, religijnych czy społecznych (internaty, szkoły prywatne, seminaria, domy dziecka). Okazało się, że w tych instytucjach ryzyko niechcianych przez dzieci kontaktów seksualnych było dwukrotnie wyższe niż średnia krajowa. Dzieci mieszkające w placówkach opiekuńczo-wychowawczych, poza domem rodzinnym, były bardziej narażone na molestowanie seksualne niż ich rówieśnicy przebywający cały czas ze swymi rodzicami.

Niezwykle ważny fragment Raportu Komisji dotyczy korekty obrazu medialnego, jaki powstał w Holandii po 2010 r. odnośnie do zjawiska pedofilii. „Po pierwsze, trzeba zweryfikować wrażenie wykreowane przez media, jakoby wykorzystywanie seksualne nieletnich dotyczyło przede wszystkim Kościoła rzymskokatolickiego. Wykorzystywanie seksualne nieletnich występuje powszechnie w społeczeństwie holenderskim. Po drugie, molestowanie seksualne nie występuje głównie w instytucjach wychowawczych, nawet jeśli okazało się, że był to specyficzny problem pozostajacy w relacji do tych instytucji. Jak komisja śledcza zaobserwowała już wcześniej, ryzyko nadużyć seksualnych jest większe w ramach instytucji niż gdzie indziej. To odnosi się do instytucji w ogóle, a nie konkretnie do instytucji rzymsko-katolickich. Po trzecie, istnieje rozbieżność między obrazem natury i wagi problemu wykorzystywania seksualnego w mediach a ustaleniami komisji śledczej" (Web-02: 10-11).

Komisja Deetmana stwierdziła także, że skala wykorzystywania seksualnego nieletnich w Kościele rzymskokatolickim ,jest stosunkowo niewielka w ujęciu procentowym, ale jest to poważny problem w liczbach bezwzględnych. Kilkadziesiąt tysięcy nieletnich doświadczyło łagodnych, poważnych lub bardzo poważnych form niewłaściwych zachowań seksualnych. Ofiary często cierpiały przez dziesięciolecia z powodu skutków molestowania seksualnego i otrzymały niewiele zrozumienia tego faktu. To spowodowało problemy dla nich, ich najbliższej rodziny i przyjaciół, którzy wymagają uwagi i czasem opieki specjalistycznej" (Web-o2: 19).

Po publikacji Raportu Komisji Deetmana biskupi holenderscy i przełożeni zakonni wyrazili publicznie swoje przerażenie, wstyd i smutek z powodu dramatu pedofilii i krzywdy ofiar. W listopadzie 2011 r. Kościół katolicki w Holandii powołał specjalny fundusz liczący $5 \mathrm{mln}$ euro, aby ofiary mogły otrzymać odpowiednie odszkodowania stosowne do doznanych cierpień: od 5 tys. do 100 tys. euro.

W 2014 r. władze Kościoła katolickiego w Holandii publicznie przyznały, że potwierdziły się oskarżenia o pedofilię wobec bp. Joannesa Gijsena (1932-2013), który w latach 1972-1993 sprawował urząd biskupa Roermondu w południowo-wschodniej części Holandii, a w latach 1996-2007 był biskupem stolicy Islandii Reykyavíku. Gdy pojawiły się publiczne oskarżenia w 2011 r., diecezja Roermond ustanowiła specjalną komisję do zbadania wiarygodności stawianych zarzutów. Specjalne komisje kościelne potwierdziły molestosowanie seksualne nieletnich chłopców przez tego duchownego na przełomie lat 50. i 6o. ubiegłego wieku oraz tuszowanie przypadków pedofilii innych 
duchownych. Po ogłoszeniu raportu komisji, Bp Frans Wiertz, aktualny ordynariusz diecezji Roermond, spotkał się z ofiarami, poprosił o przebaczenie, wyraził żal, współczucie i ubolewanie z powodu cierpienia ofiar.

\section{Podsumowanie}

Przeciwdziałanie różnym formom przemocy wobec dzieci jest dzisiaj niezwykle aktualnym wyzwaniem w skali globalnej. Dotyczy to także Holandii, gdzie każdego roku cierpi z powodu przemocy fizycznej, psychicznej czy seksualnej ponad 100 tys. dzieci. W ostatnich latach społeczeństwo holenderskie zmierzyło się z dramatem pedofilii, szukając adekwatnych rozwiązań. Największym zwycięstwem jest przerwanie zmowy milczenia w tej sprawie. Niestety, w Holandii - podobnie jak w innych krajach - do końca lat 8o. ubiegłego wieku molestowanie seksualne dzieci było tematem tabu, ponieważ dominowała w społeczeństwie tzw. kultura milczenia.

Wydaje się, że w Holandii nastąpiło w ostatnich 50 latach swego rodzaju sprzężenie zwrotne: z jednej strony, rewolucja seksualna 1968 r., gwałtowny proces głębokiej sekularyzacji i narodziny nowej moralności stworzyły podatny grunt dla rozwoju zjawiska pedofilii, z drugiej - dramat seksualnego wykorzystywania osób nieletnich przyczynił się do jeszcze głębszego rozpadu tradycyjnej religijności społeczeństwa holenderskiego i stopniowego rozbicia Kościoła katolickiego i innych denominacji chrześcijańskich.

Specyfiką kraju tulipanów jest nie tyle skala ofiar czynów pedofilskich, ile funkcjonowanie bardzo wpływowych środowisk politycznych i społecznych, które dążą do legalizacji pedofilii. W latach 2006-2010 istniało $\mathrm{w}$ tym kraju legalnie działające ugrupowanie polityczne o nazwie „Partia na rzecz Miłości Bliźniego, Wolności i Różnorodności”, które chciało wejść do parlamentu, aby walczyć na drodze parlamentarnej o prawa pedofilów. Działacze tej partii byli powiązani z holenderską organizacją pedofilską "Sticthing Martijn”, która została ostatecznie zdelegalizowana dopiero w 2015 r. - po kilkudziesięciu latach jawnej działalności.

Dyskusja społeczna prowadzona w Holandii wokół wykorzystywania seksualnego dzieci zwraca także uwagę na poważny problem związany z najnowszymi formami cyberpedofilii i ogromną ilością materiałów pornografii dziecięcej, które są dostępne w ukrytej przestrzeni elektronicznej Deep Web. Pozytywnym elementem debaty wokół pedofilii są różnego rodzaju inicjatywy społeczne, które służą pomocy ofiarom wykorzystywania seksualnego i wzmacniają ochronę osób nieletnich przed różnymi formami przemocy. Jedną z ważnych organizacji, zajmujących się pomoca ofiarom pedofilii jest Stowarzyszenie „Mea Culpa”.

Skandal pedofilii w Holandii ma ogromny wpływ na debatę światopoglądową, etyczną i bioetyczną prowadzoną w tym kraju. Tuszowanie wykorzystywania seksualnego dzieci m.in. przez wiele kościołów i związków wyznaniowych doprowadziło do utraty przez te podmioty dużej części ich pozycji społecznej i siły moralnej. Wypowiedzi przedstawicieli tych organizacji na temat sztucznego zapłodnienia czy eutanazji nie mają dzisiaj tego znaczenia, jakie miały jeszcze 20 czy 30 lat temu. Drastyczne obniżenie siły moralnej różnych wspólnot chrześcijańskich i ich praktyczne wymieranie prowadzą do wzmocnienia innych środowisk światopoglądowych, które opowiadają się za bardzo liberalnymi rozwiązaniami w ramach współczesnej rewolucji obyczajowej i biotechnologicznej.

Przez tysiąclecia akceptowano w całym świecie niewolnictwo, segregację rasową czy niehumanitarne traktowanie osób chorych psychicznie. Zmiana świadomości społecznej w tych kwestiach zajęła całej ludzkości wiele epok historycznych. Wydaje się, że podobną drogę przechodzi obecnie ocena zjawiska pedofilii w wymiarze planetarnym. Dopiero w ostatnim czasie budzi się nowa wrażliwość moralna, gdy chodzi o ochronę dzieci przed różnymi formami wykorzystywania seksualnego. Ma rację Fortunato Di Noto - włoski duchowny, znany na świecie 
ze swej walki z pedofilią - który twierdzi, że kto milczy w tej sprawie, staje się współwinny wielkiego dramatu, który może być nazwany cichym holokaustem obecnego stulecia.

\section{Bibliografia}

Bellaspiga L., 2016, Guardate in faccia l'orrore. Il dossier 2015 di Meter sulla pedofilia: piaga in espansione, Avvenire, nr 64, 10.

Deetman W., 2011, Seksueel misbruik van minderjarigen in de Rooms-Katholieke Kerk, Uitgeverij Balans, Amsterdam.

Di Noto F., 2002, La pedofilia. I mille volti di un olocausto silenzioso, Paoline Editoriale Libri, Milano.

Dreissen J., 1968, Diagnose des Holländischen Katechismus. Über Struktur und Methode eines revolutionierenden Buches, Herder Velrag, Freiburg - Basel - Wien.

Guenzi P. D., 2004, Pedofilia, in: Nuovo Dizionario di Bioetica, red. S. Leone, S. Privitera, Città Nuova Editrice - Edizioni ISB dell'Istituto Siciliano di Bioetica, Roma - Arcireale, 843-852.

Introvigne M., Marchesini R., 2014, Pedofilia. Una battaglia che la Chiesa sta vincendo, Sugarco Edizioni, Milano.

Kelly M., 2015, This Time in the Church, ATF Press, Adelaide.

Kershnar S. 2015, Pedophilia and Adult Child Sex: A Philosophical Analysis, Lexington Books, New York - London.

Kobyliński A., 1994, Sul destino dell'uomo nella società borghese, „Collegium Polonorum" nr 12, 11-28.

Krzemiński A., 2005, Wolność w tóżku i wolność w ogóle, Polityka, $\mathrm{nr}$ 11, 30-33.

Lee K., 2013, Unholy Silence: Covering Up the Sins of the Fathers, Kevin Lee, Kindle Edition - Amazon Digital Services, Seattle.

Marcuse H., 1998, Eros i cywilizacja, tłum. H. Jankowska, A. Pawelski, Wydawnictwo Literackie Muza, Warszawa.
McGillion Ch., Grace D., 2014, Reckoning: The Catholic Church and Child Sexual Abuse, ATF Press, Adelaide.

Salter M., 2014, Organised Sexual Abuse, Routledge Press, Abingdon.

Sguotti S., 2015, Prete pedofilo si diventa. Pedofilia e celibato nella Chiesa di papa Francesco, Edizioni La Zisa, Palermo.

Townsend D., 2013, Child Abuse and the Church, David Townsend, Kindle Edition - Amazon Digital Services, Seattle.

Zechenter A., 2008, Czerwony Dany, Ośrodek Myśli Politycznej, Kraków.

(Web-o1) Seiterich Th., Kardinal Pell missbraucht seine Kirche, https://www.publik-forum.de/Religion-Kirchen/kardinal-pell-missbraucht-seine -kirche, dostęp: 5.06.2016.

(Web-02) Deetman W., Sexual abuse of minors in the Roman Catholic Church,

http://www.onderzoekrk.nl/fileadmin/commissiedeetman/data/downloads/eindrapport/20111216/ Samenvatting_eindrapport_Engelstalig.pdf, dostęp: 5.06.2016.

(Web-o3) Guerra M., Sindaci all'attacco: obiezione di coscienza alle unioni gay, http://www.lanuovabq.it/it/articoli-sindaci-allattacco-obiezionedi-coscienza-alle-unioni-gay-15728.htm, dostęp: 5.06.2016.

(Web-04) Matzuzzi M., Olanda senza Cristo, http://www.ilfoglio.it/articoli/2015/01/26/olandasenza-cristo_1-v-124926-rubriche_c503.htm, dostęp: 5.06.2016.

(Web-05) Amato G., L'ascesa mondiale del partito dei pedofili,

http://www.lanuovabq.it/it/articoli-lascesa-mondialedel-partitodei-pedofili-7988.htm, dostęp: 5.06.2016.

(Web-06) Marchesini R., Pedofilia „variante naturale della sessualità umana"?,

http://www.libertaepersona.org/wordpress/2011/04/ pedofilia-variante-naturale-della-sessualit-umana-2434, dostęp: 5.06.2016. 


\section{Pedophilia in the Netherlands: causes, consequences, moral judgment}

\section{Summary}

The main purpose of this article is to analyze the phenomenon of pedophilia in the Netherlands and to present the most important ethical and legal aspects of child sexual abuse. It seems that in this country there has been a kind of social feedback: on the one hand, the sexual revolution of the 1960s, a process of deep secularization of Dutch society and the birth of a new morality have created fertile ground for the development of the phenomenon of pedophilia, on the other - a drama of sexual abuse of minors contributed to even deeper breakdown of the traditional understanding of morality and religion, causing the gradual collapse of the Catholic Church and other Christian denominations. There is a bulk of informations about pedophilia in the Netherlands in a special report published by the Wim Deetman's Inquiry Commission in 2011. The drama of child sexual abuse in this country is a small part of a big phenomenon in the global scale. The key issue in this dispute about child sexual abuse is a reliable philosophical argumentation, which draws attention to the moral evil and its inclinations of sexual relationship between adults and children.

\section{Key words}

pedophilia, child sexual abuse, pedopornography, sexual revolution, secularization, children's rights, sexual orientation 